\title{
Local knowledge in community-based approaches to medicinal plant conservation: lessons from India Shailesh Shukla* ${ }^{\dagger}$ and James Gardner ${ }^{\dagger}$
}

\author{
Address: Natural Resources Institute, University of Manitoba, Winnipeg, MB, R3T2N2, Canada \\ Email: Shailesh Shukla* - shaileshshukla@yahoo.com; James Gardner - gardner@cc.umanitoba.ca \\ * Corresponding author †Equal contributors
}

Published: 07 April 2006

Journal of Ethnobiology and Ethnomedicine2006, 2:20 doi:10.1 186/1746-4269-2-20

This article is available from: http://www.ethnobiomed.com/content/2/1/20

(C) 2006Shukla and Gardner; licensee BioMed Central Ltd.

This is an Open Access article distributed under the terms of the Creative Commons Attribution License (http://creativecommons.org/licenses/by/2.0), which permits unrestricted use, distribution, and reproduction in any medium, provided the original work is properly cited.
Received: 25 January 2006

Accepted: 07 April 2006

\begin{abstract}
Background: Community-based approaches to conservation of natural resources, in particular medicinal plants, have attracted attention of governments, non governmental organizations and international funding agencies. This paper highlights the community-based approaches used by an Indian NGO, the Rural Communes Medicinal Plant Conservation Centre (RCMPCC). The RCMPCC recognized and legitimized the role of local medicinal knowledge along with other knowledge systems to a wider audience, i.e. higher levels of government.
\end{abstract}

Methods: Besides a review of relevant literature, the research used a variety of qualitative techniques, such as semi-structured, in-depth interviews and participant observations in one of the project sites of RCMPCC.

Results: The review of local medicinal plant knowledge systems reveals that even though medicinal plants and associated knowledge systems (particularly local knowledge) are gaining wider recognition at the global level, the efforts to recognize and promote the un-codified folk systems of medicinal knowledge are still inadequate. In country like India, such neglect is evident through the lack of legal recognition and supporting policies. On the other hand, community-based approaches like local healers' workshops or village biologist programs implemented by RCMPCC are useful in combining both local (folk and codified) and formal systems of medicine.

Conclusion: Despite the high reliance on the local medicinal knowledge systems for health needs in India, the formal policies and national support structures are inadequate for traditional systems of medicine and almost absent for folk medicine. On the other hand, NGOs like the RCMPCC have demonstrated that community-based and local approaches such as local healer's workshops and village biologist program can synergistically forge linkages between local knowledge with the formal sciences (in this case botany and ecology) and generate positive impacts at various levels.

\section{Background}

\section{Purpose and objectives of the research}

The contribution of local knowledge systems in conservation and sustainable use of natural resources is gaining wider recognition [1]. Local knowledge associated with the use and conservation of medicinal plants is either codified in ancient scriptures or is folk-based and transmitted through generations in the form of community-based health traditions. The codified knowledge has managed to expand globally through official recognition and some 
Table I: Comparisons of the features and policy issues of local medicinal plant knowledge: The folk and codified systems of medicine in India

\begin{tabular}{|c|c|}
\hline Folk traditions of local medicinal plant knowledge & TSM of local medicinal plant knowledge \\
\hline $\begin{array}{l}\text { Originated in communities to meet daily healthcare/survival needs, } \\
\text { largely undocumented }\end{array}$ & $\begin{array}{l}\text { Originated by scholars, physicians and seers and documented in } \\
\text { manuscripts/Vedic texts( } 1000-1500 \mathrm{BC}) \text {, scriptures for human well- } \\
\text { being and developed as a classified main branches }\end{array}$ \\
\hline $\begin{array}{l}\text { Transmission multigenerational and by oral means through learning-by } \\
\text { doing and through more than } 300 \text { formal educational colleges }\end{array}$ & $\begin{array}{l}\text { Transmission is often institutionalized through written texts and hands- } \\
\text { on training }\end{array}$ \\
\hline Mainly empirical, adapted & $\begin{array}{l}\text { Sophisticated philosophical and theoretical roots with a scope for } \\
\text { refinement }\end{array}$ \\
\hline $\begin{array}{l}\text { No legal status, No budgetary allocation, on the contrary vulnerable to } \\
\text { disregard and devaluation }\end{array}$ & $\begin{array}{l}\text { Legal status as 'Indian Systems of Medicine' with five percent of } \\
\text { budgetary allocation (health) wider social and official acceptance and } \\
\text { recognition }\end{array}$ \\
\hline $\begin{array}{l}\text { Approximate \# practitioners are } 600,000 \text { birth attendants, } 60,000 \text { bone } \\
\text { setters, } 100,000 \text { herbal healers, } 60,000 \text { healers specialized in treating } \\
\text { poisonous snake bites and millions of households/women }\end{array}$ & $\begin{array}{l}\text { Approximately } 600,000 \text { registered medicinal practitioners, out of which, } \\
10 \text { percent practice medicine on the basis of TSM. }\end{array}$ \\
\hline Uses more than 7,500 medicinal plants & $\begin{array}{l}\text { The four streams of Ayurvedic, Unani, Siddha and Tibetan uses } \\
\text { approximately } 4,500 \text { medicinal plants }\end{array}$ \\
\hline \multicolumn{2}{|c|}{ POLICY LEVEL ISSUES } \\
\hline $\begin{array}{l}\text { Local state and national incentives for systematic documentation and } \\
\text { dissemination needed }\end{array}$ & $\begin{array}{l}\text { Available documentation in Sanskrit at scattered places, interpretation } \\
\text { and consolidation in a commonly-understood language will facilitate } \\
\text { further use/research }\end{array}$ \\
\hline $\begin{array}{l}\text { In-depth understanding of and incentives for (local/state/national/global) } \\
\text { incentives can facilitate transmission }\end{array}$ & Formal institutions for transmission are present but are poorly funded \\
\hline $\begin{array}{l}\text { Sustaining interest and apprenticeship of the younger generations is a } \\
\text { challenge }\end{array}$ & Maintaining quality and standards of practitioners is a challenge \\
\hline $\begin{array}{l}\text { Scope of learning from TSM and allopathic medicine system is limited } \\
\text { due to access, affordability and literacy issues at the community level }\end{array}$ & $\begin{array}{l}\text { Both TSM and allopathic medicine draw heavily on the folk system for } \\
\text { herbal remedies or drugs without giving credit or sharing benefits to } \\
\text { local communities }\end{array}$ \\
\hline $\begin{array}{l}\text { Benefit sharing mechanisms are developing and difficult to implement at } \\
\text { community level }\end{array}$ & $\begin{array}{l}\text { Well-established and implemented benefit sharing mechanism in the } \\
\text { form of patent/trademarks and other forms of protection }\end{array}$ \\
\hline $\begin{array}{l}\text { Efficacy, standardization and safety studies using scientific parameters are } \\
\text { almost nil due to lack of authentic documentation and neglect by official } \\
\text { policies }\end{array}$ & $\begin{array}{l}\text { Efficacy, standardization and safety studies are not encouraged due to } \\
\text { high-cost ( } 200,000 \text { US } \$ \text { ) and time consuming (8-10 years) scientific } \\
\text { validation and language barriers }\end{array}$ \\
\hline $\begin{array}{l}\text { Collaboration by other stakeholders is difficult and confined to } \\
\text { documentation/dissemination efforts }\end{array}$ & $\begin{array}{l}\text { Collaboration is generally encouraged if the epistemological and } \\
\text { philosophical foundations are matching }\end{array}$ \\
\hline
\end{tabular}

Sources: Compiled based on Shankar (200I)[I I], Shankar and Venkatasubramanian (2004)[15] and WHO (2002)[6]

corresponding policy and financial support. The largely undocumented folk-based knowledge and traditions, on the other hand, have survived on their own in the absence of any official recognition and policy and administrative support by governments at the state and national levels [2]. The problems, progress, and prospects of folk and codified streams are therefore distinct, with the former deserving more attention. Despite the lack of official recognition and support, the recent efforts and approaches of grassroots community groups and NGOs in revitalizing and promoting folk knowledge systems of medicine are noteworthy. The purpose of this paper is to describe and analyze such an NGO-led approach from India in order to demonstrate the contributions of local knowledge systems in generating positive outcomes at the local, the regional, the national and the global levels. The specific objectives of the paper are:

i) to describe the community-based approaches taken by the RCMPCC (Rural Commune's Medicinal Plant Conservation Centre) that successfully used folk and codified local medicine systems along with formal medical systems

ii) to understand the outcomes of these community-based approaches at the various levels in order to derive lessons for policy and practice in regard to community-based medicinal plant conservation

\section{The global status of local medicinal plant knowledge systems}

Medicinal plants are gaining wider recognition in recent initiatives for conservation and development at the global level. This is evident in the vision and mission statement of World Health Organization (WHO) on health improvement and in community-based conservation initiatives by international organizations, including the World Bank, the International Development Research Centre (IDRC) and UNDP, for example. The effort by the WHO to recognize and promote the use of local medicinal plant knowledge systems in the health sector, particularly in developing countries, is prominent. The terminologies 
related to a use of plant-based medicine vary in different cultures, countries, and communities. The WHO, in its widely acknowledged report, uses an umbrella term 'traditional medicine' to describe such uses and offers its working definition as 'diverse health practices, approaches, knowledge and beliefs incorporating plant, animal, and/ or mineral based medicines, spiritual therapies, manual techniques and exercises applied singularly or in combination to maintain well-being, as well as to treat, diagnose or prevent illness' [6]. The scope of this paper is limited to practices/approaches/knowledge with respect to only plant-based medicines.

The World Bank report [7] indicates that more than eighty percent of the population of South Asia uses plant-based medicines for maintaining and improving their health. The total reported usages of medicinal plants vary. For instance, the WHO [6] study lists 21,000 plants with reported medicinal uses around the world, while Schippmann and co-workers [8] estimated this figure as 52,885. Amidst these conflicting claims on numbers, the use of medicinal plants by local communities or groups has remained high. Such local uses of medicine, are again known by different terms but can be classified broadly into the following three categories[9]: (i) Traditional Systems of Medicine (TSM), with a systematic codified body of knowledge either in the form of pharmacopoeias or ancient scriptures [Ayurvedic, Chinese and Tibetian medicine, Siddha, Unani (Arabic) etc.]; (ii) Traditional Medical Knowledge or Folk Medicine, which is transmitted by oral means and is mostly acquired through learning-bydoing approaches, and (iii) Shamanistic or Spiritual Medicine, with a strong religious/spiritual element and can be practiced only by highly specialized local experts called 'shamans'. In general, except for TSM, the legal and political recognition and support for folk and spiritual medicine at the national and the global level (see, Table 1) has remained weak $[10,11]$. The lack of official and governmental support, compounded by the devaluation of the folk knowledge [12] by local communities and societal systems at large, has resulted in the erosion of the local medicinal plant knowledge systems. The issues related to the formal recognition of TSM, and the lack thereof for other medicinal plant knowledge systems (folk and spiritual), have some things in common. However, in most cases, the distinct lack of attention to the latter systems suggests that they deserve further consideration in countries like India, China and South Africa, where a reliance on TSM and folk medicine is more widespread and evident.

\section{The local medicinal plant knowledge systems in India}

In a country like India, where 65 percent of the total population has access to only local medicinal plant knowledge systems [6], and 70 percent of the population lives in villages struggling to access and afford modern allopathic medicines, both TSM and the folk knowledge systems of medicine are of significance[13] TSM exists in the form of well-known classical traditions of Ayruevda, Unani and Siddha, which are characterized by a large number of practitioners trained through formal institutions, a well-codified body of texts either in the form of the scriptures or other written forms and an official recognition as 'Indian Systems of Medicine'[14]. Both Ayurvedic and Siddha systems of medicine originated more than 3000 years ago and were prevalent in North and South India, respectively. The Unani system of medicine originated in Greece (460$377 \mathrm{BC})$, and became more popular in India after the establishment of the Central Council for the Research in Indian Medicine and Homeopathy in 1969. Complementary to these codified systems, the folk knowledge systems are largely transmitted through oral means and flourish at the village level [15] with little or negligible support from official channels at the state or the national level. The features and policy issues concerning these systems are compared in Table 1.

Although folk knowledge ranks at the top in terms of the total number of users, the number of medicinal plants used and number of practitioners, the desired policy support for its recognition and development is not evident. There is some policy and legal support for the codified systems of Ayurvedic, Unani and Siddha in India [6] but it is inadequate [15].

International organizations like UNDP, IDRC, OXFAM, WHO, Ford Foundation and the World Bank are the leading sources of funding for broad-based programs dealing with medicinal plant conservation and development in India and Asia [16]. The funding and capacity building support of these agencies to Indian governments and NGOs is predominant in developing state, national, and regional visions and strategies for participatory, comprehensive, and sustainable management of medicinal plants. At a national level, the Department of the Indian Systems of Medicine (Health) and the Medicinal Plant Boards [17] are the most relevant government agencies that deal directly with the medicinal plant sector and associated local knowledge systems. These national level efforts are more recent and more targeted at improvement in codified streams such as TSM. Further, their direction, design and delivery have largely been limited to the state level. At the sub-state level (district, block or taluka and village), the programmatic interventions related to medicinal plant and associated local knowledge systems are organized by local NGOs and community groups.

The most notable and oldest among these NGOs is the Foundation for Revitalization of Local Health Traditions (FRLHT) [2], which has been identified and supported by 
the Government of India as a 'centre of excellence' in the field of medicinal plants. FRLHT's programs and activities in this sector are largely confined to peninsular and Southern India. Nevertheless, FRLHT has inspired similar initiatives in other parts of India and Asia through networking and capacity building for other NGOs. The RCMPCC, based in the western state of Maharashtra is one such NGO. The RCMPCC has demonstrated that the use of community-based participatory approaches at the local level facilitates learning among various stakeholders and provides a platform for interactions among the formal botanical knowledge, TSM and the folk knowledge systems relevant to medicinal plants at the state level. The learning resulting from these local knowledge-based approaches has transformed the agenda of medicinal plant conservation at the sub-state or state level in Maharashtra and has the potential to enrich and inform stakeholders at the national and global levels.

\section{Methods}

Before the start of field research activities, a series of consultations was held at the Center for Community-based Natural Resources Management at Natural Resources Institute (NRI), University of Manitoba, Winnipeg, Canada between April and October 2003 as a part of the Equator Initiative of the United Nations Development Program (UNDP). This helped in the selection of communities, research objectives and field research methods. The RCMPCC of Pune, India was one of the four Equator Initiative sites selected as part of the study. The purpose, objectives and research design were based on an interactive adaptive approach as suggested by Nelson [3] and were shared with key leaders and field staff of RCMPCC. The RCMPCC had established thirteen project sites in the rural, tribal and forested areas known as medicinal plan conservation areas across the state of Maharashtra. One of their project sites near the village of Amboli was chosen as a case study, on the basis of the following criteria:

a) Willingness of the community/project functionaries to participate: The willingness and oral consent of villagers were addressed and obtained in local dialects during an initial workshop in Amboli that was attended by the village panchayat, i.e., local management committee members. Special efforts (e.g. personal visits or informal conversations while walking in forest) to ensure written consent and active participation of special groups, such as women and local healers, were made.

b) Evidence of use of local knowledge in sustainable management of local biodiversity: Amboli has well-documented evidence for community-based conservation and is rated as one of the best examples of such $(267.63 \mathrm{hec}-$ tares) by the RCMPCC [4].
A review of literature was undertaken on issues related to medicinal plants and associated local knowledge systems to contextualize the problem as described in the background. The field research used a variety of qualitative research tools [5] such as semi-structured interviews with key people $(\mathrm{N}=12)$ from the RCMPCC, local healers $(\mathrm{N}$ $=11$, seven male and four female), community members $(\mathrm{N}=5)$ and Forest Department officials $(\mathrm{N}=3)$. The selection of the research participants was limited to those who were involved in designing, implementing and/or participating in the two community-based approaches (i.e. vaidu sammelan and village biologist program) of RCMPCC. For the purpose of this paper, data relevant to the outcomes (as perceived as 'benefits' or 'visible impact' by the research participants) were collected and analyzed. The senior author stayed in Amboli for more than three months and participated in a village botanist training program organized at Amboli (December 2003) and vaidu sammelan (March 2004). The field research was complemented by a review of relevant documents and internal documents (such as proceedings of the village botanists' workshops (December 2000 and November 2001) provided by RCMPCC.

The Joint-Faculty Research Ethics Board at University of Manitoba approved the research protocols (Protocol No. J2003:141) for this study.

\section{Results and discussion}

This section describes and analyzes two community-based approaches undertaken by RCMPCC, which combine both local (folk and codified) and formal systems of medicine to demonstrate that such creative integration at the local level can generate positive impacts at all levels.

\section{Building on medicinal plant knowledge of local healers: the RCMPCC way}

The RCMPCC initiative was envisioned by a Mumbaibased NGO, called Rural Commune for the In-Situ Conservation and Sustainable Utilization of the Medicinal Plant Diversity of Maharashtra, through developing partnerships among the Forest Department, local communities and NGOs. To this end, the RCMPCC, in collaboration with other stakeholders, organized several activities, such as the establishment of a network of 13 Medicinal Plant Conservation Area or MPCAs (each ranging from 250-400 hectares) in Maharashtra. The MPCAs were selected in consultation with the Forest Department, local communities, and available scientific literature, based on the following criteria:

- Relatively undisturbed forest areas representing different bio-climatic zones

- Forest areas with rich biodiversity 


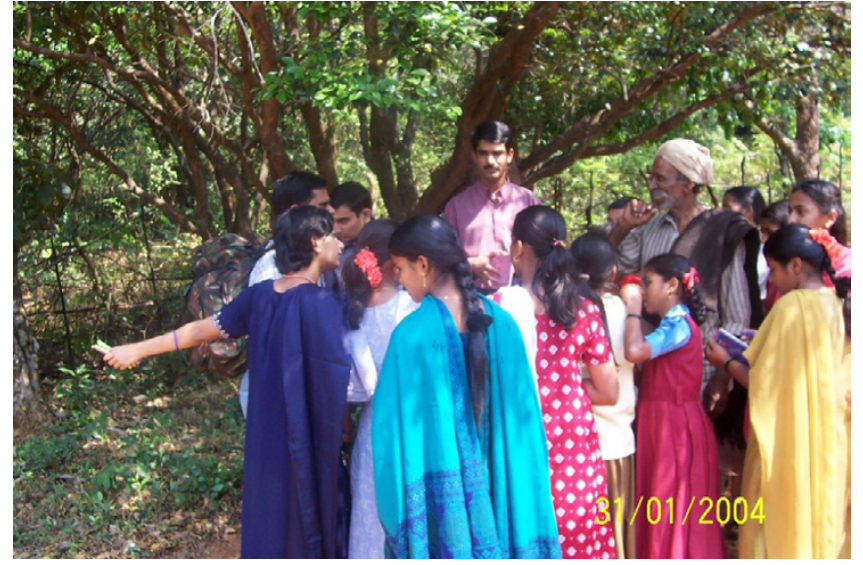

Figure I

Local vaidus, RCMPCC scientists and school students engaged in knowledge exchange during the village biologist workshop in Amboli (Photo- JPEG format)

- Areas with natural availability of water

- Locally and otherwise known for harboring medicinal plants.

The MPCAs were legally notified by the Maharashtra Forest Department as permanent medicinal plant reserves and this inspired other state governments and the Government of India to include them in their conservation and development agenda. The RCMPCC also completed the documentation of some 150 species in the Medicinal Plant Conservation Areas through participatory approaches like the village biologist program, the Conservation Assessment and Management Program, local healers' conventions and scientific assessments by field botanists. They created village management structures such as Local Management Committees (LMCs) and SelfHelp Groups (SHGs) for marketing and local sale of herbal products [18].

A group of individuals known as local knowledge experts or healers and ecological experts called vaidus were identified by the RCMPCC. The term vaidus is a generic folk term most commonly used in the Marathi and Hindi languages to describe healers and traditional herbal practitioners, used most commonly for, but not limited to, male healers. These vaidus possessed extraordinary knowledge and interest in the local plants, fauna and ecosystems. Many of the vaidus practiced herbal treatments for diseased humans, livestock, and crops and developed skills in identification and use of locally grown plants. The RCMPCC recognized the creative potential of the vaidus as village biologists (VB) or barefoot botanists in the conservation and management of medicinal plant diversity through sustainable uses [19]. To build effective partnerships with the local knowledge experts, the RCMPCC organized two programs: 1) vaidu sammelan or local healer's workshops, and 2) the village biologists (previously known as barefoot botanists) training programs. FRLHT initiated the Barefoot Botanist (BFB) program in 1995 with the original aim to enrich the local medicinal plant knowledge of the village vaidus with the relevant formal botanical skills. The trained vaidus were expected to perform better in their own profession and in providing guidance to eco-tourists and researchers. RCMPCC prefers the use of more inclusive term 'village biologist' instead of 'barefoot botanist'. These programs also helped in mutual learning and the strengthening of the capabilities of formally-trained botanists and local vaidus through dialogue and exchange of knowledge. (See, Figure 1)

The purpose of vaidu sammelan was to: 1) document the knowledge of local vaidus about plants; 2) encourage value-added activities by promoting local use and sale of herbal products; 3 ) provide a platform for vaidus to demonstrate their products; and, 4) to provide a platform for the vaidus and other health practitioners to interact and encourage participation in local biodiversity conservation efforts. The village biologist program was broad in terms of coverage, with 3 or 4 local experts identified at each location. Selection of village biologists was based on: 1) good knowledge of local plants and their uses and cultural significance; 2) interest in local environmental and conservation issues; and, 3) ability to read and write. Most village biologists identified were vaidus, forest guards and knowledgeable elders.

\section{Learning from the outcomes of RCMPCC's community- based approaches}

The discussion in this section draws mainly on interviews with selected informants (as indicated in methods) and a review of relevant documents.

Table 2 highlights some of the major outcomes of these two methods, along with the policy implications, at various levels of activity. These levels are geographical units or operations at which the various activities of the RCMPCC has generated visible impacts, as perceived by RCMPCC and the communities including the vaidus.

At the village level, the local medicinal plant knowledge of the vaidus is widely recognized as 'valid' alternative systems of knowledge. 'This is the most commonly available knowledge in our village and people often seek our help, even during odd times such as night. We treat many villagers who have snake bites during night or are injured by black bear when we work in our farms near forest' (SA, local vaidu, Amboli, March, 2004). Amboli has a Public health centre but the continuous availability of allopathic practitioners is normally not the case. The accessibility of 
Table 2: Major outcomes of RCMPCC's community-based programs

\begin{tabular}{|c|c|c|c|c|c|}
\hline Major Outcome & Levels of influence & & & & \\
\hline Policy implication & Village/Sub-district & District (MPCA) & State (RCMPCC) & National & Global \\
\hline $\begin{array}{l}\text { Documentation of } \\
\text { traditional knowledge } \\
\text { of medicinal plants } \\
\text { from vaidus- both men } \\
\text { and women } \\
\text { Systematic } \\
\text { documentation created } \\
\text { opportunities for } \\
\text { collaborative research } \\
\text { with TSM }\end{array}$ & $\begin{array}{l}\text { Role of women vaidus } \\
\text { recognized } \\
\text { Involvement of vaidus/ } \\
\text { VB in village } \\
\text { development/ } \\
\text { conservation activities }\end{array}$ & $\begin{array}{l}\text { Two local language } \\
\text { booklets on ethno } \\
\text { botanical information } \\
\text { about plants and } \\
\text { vaidus }\end{array}$ & $\begin{array}{l}\text { Systematic data base } \\
\text { on } 326 \text { medicinal } \\
\text { plants, } 465 \text { herbal } \\
\text { formulations, Illness- } \\
\text { specific database on } \\
265 \text { plants, herbarium } \\
\text { record of } 804 \text { species }\end{array}$ & $\begin{array}{l}\text { Raw drugs } \\
\text { formulations of } 75 \\
\text { plants available for } \\
\text { further scrutiny }\end{array}$ & $\begin{array}{l}\text { VB, Vaidus training } \\
\text { institutionalized in } \\
\text { GEF programs in nine } \\
\text { states }\end{array}$ \\
\hline $\begin{array}{l}\text { Local assessment of } \\
\text { Rare, Endangered and } \\
\text { Threatened (RET) } \\
\text { species } \\
\text { Potential of Local } \\
\text { medicinal knowledge } \\
\text { alongside TSM as inputs } \\
\text { in official planning }\end{array}$ & $\begin{array}{l}\text { Local monitoring by } \\
\text { panchayats (village } \\
\text { councils), LMCs, } \\
\text { SHGs. } \\
\text { RET List maintained at } \\
\text { two MPCA by local } \\
\text { communities with the } \\
\text { support of VBs/vaidus }\end{array}$ & $\begin{array}{l}\text { Training of } 36 \\
\text { selected VB and } \\
\text { district forest officers } \\
\text { on RET monitoring } \\
\text { Incorporating list in } \\
\text { district working plans } \\
\text { of Forest Department }\end{array}$ & $\begin{array}{l}\text { Prioritized species } \\
\text { identified and raised in } \\
\text { seven forest nurseries } \\
\text { of the state } \\
\text { Helped FD in species } \\
\text { recovery and } \\
\text { enrichment programs }\end{array}$ & $\begin{array}{l}\text { Unique species } \\
\text { highlighted }\end{array}$ & $\begin{array}{l}\text { Unique specie of } \\
\text { Global importance } \\
\text { identified at Leghapani } \\
\text { MPCA }\end{array}$ \\
\hline $\begin{array}{l}\text { Recognition and use } \\
\text { of vaidus } \\
\text { Official recognition of } \\
\text { Local knowledge experts } \\
\text { (restricted up to sub- } \\
\text { state level) }\end{array}$ & $\begin{array}{l}\text { Vaidus Involved in } \\
\text { selection of } \\
\text { appropriate seedlings } \\
\text { in forest nurseries } \\
\text { Vaidus and VB got } \\
\text { 'official' recognition to } \\
\text { practice their } \\
\text { knowledge }\end{array}$ & $\begin{array}{l}\text { Employing vaidus as } \\
\text { field guides/eco- } \\
\text { tourism } \\
\text { Honouring VB/vaidus } \\
\text { in two workshops }\end{array}$ & $\begin{array}{l}\text { State level database of } \\
\text { vaidus and village } \\
\text { botanists according to } \\
\text { their area of expertise } \\
\text { (RCMPCC) } \\
\text { CAMP exercises }\end{array}$ & $\begin{array}{l}\text { Display and dialogue } \\
\text { with other national } \\
\text { level vaidus through } \\
\text { two national herbal } \\
\text { expos }\end{array}$ & $\begin{array}{l}\text { Local vaidus guided } \\
\text { ITTO (Japan) research } \\
\text { scientists as research } \\
\text { anchors in vegetation } \\
\text { mapping }\end{array}$ \\
\hline $\begin{array}{l}\text { Opportunities for } \\
\text { collaborative research } \\
\text { Collaborative Research } \\
\text { mainly initiated at } \\
\text { national/below level and } \\
\text { often self-inspired/ } \\
\text { funded }\end{array}$ & $\begin{array}{l}\text { A herbarium } \\
\text { preparation } \\
\text { techniques learned by } \\
\text { VB and vaidus through } \\
\text { botanists } \\
\text { Validation of vaidus/ } \\
\text { VB's local knowledge } \\
\text { through sharing/ } \\
\text { exchange with } \\
\text { botanists }\end{array}$ & $\begin{array}{l}\text { Selected VB/vaidus as } \\
\text { trainers for other } \\
\text { MPCA selected } \\
\text { Study in sacred groves } \\
\text { by RCMPCC }\end{array}$ & $\begin{array}{l}\text { Market study of } 22 \\
\text { medicinal plants } \\
\text { Biodiversity } \\
\text { assessment of select } \\
\text { MPCAs } \\
\text { RCMPCC as a } \\
\text { resources institution } \\
\text { in State medicinal } \\
\text { Plant Board }\end{array}$ & $\begin{array}{l}\text { Pilot project on } \\
\text { standardization/ } \\
\text { cultivation processing } \\
\text { of prioritized species } \\
\text { in six MPCAs } \\
\text { supported by } \\
\text { Department of } \\
\text { Science and } \\
\text { Technology }\end{array}$ & \\
\hline $\begin{array}{l}\text { Transmission of folk } \\
\text { knowledge facilitated } \\
\text { Systematic efforts for } \\
\text { understanding } \\
\text { transmission are lacking } \\
\text { at State/National/Global } \\
\text { levels }\end{array}$ & $\begin{array}{l}\text { People Biodiversity } \\
\text { register at one village } \\
\text { Herbarium sheets } \\
\text { demonstration in } \\
\text { three schools }\end{array}$ & $\begin{array}{l}\text { I I demo gardens, I0 } \\
\text { interpretation center } \\
\text { highlighting } \\
\text { contributions of VB/ } \\
\text { vaidus, } 40 \text { home herbal } \\
\text { gardens }\end{array}$ & & $\begin{array}{l}\text { Ministry of tribal } \\
\text { affairs supported } \\
\text { study on people's } \\
\text { biodiversity register }\end{array}$ & \\
\hline
\end{tabular}

Source: self-compiled

vaidus at anytime, therefore, is regarded as one of the major benefits for the local communities. 'Approaches such as the vaidu sammelan give our vaidus a communityrecognized local licence to practice' (MG, Community leader, Amboli, January, 2004). In addition, the village biologist program provides avenues to facilitate the use of the local medicinal plant knowledge of the vaidus by the local formal institutions in two ways: i) vaidus' knowledge about the rare and endemic medicinal plants was used in the selection of plant species in the nurseries by the Forest Department; ii) vaidus learned the herbarium preparation techniques from the botanists during the village biologist program and applied their training by conducting demonstrations of local plants through these herbarium sheets in secondary schools. The People's Biodiversity Register program has been initiated at Chavni village in the Amba Valley MPCA through consultation with the vaidus and villagers. This 100 page register was prepared in English and Marathi language. It contains useful information about the local biodiversity in and around Chavni village and details about the vaidus. The register has been useful 
in local biodiversity assessment, conservation and monitoring.

The vaidus of all thirteen Medicinal Plan Conservation Areas were involved in the identification of Rare, Endangered and Threatened (RET) plant species. At the Amboli and Leghapani MPCAs, vaidus generated a list (in the local language) and photographs of these species, for regular monitoring and regeneration in villagers' home gardens. 'We share the photographs and lists of rare plants with tourists and researchers, so they become sensitive to these plants when they move around in forest' (KG, local vaidu, Amboli, March 2004).

Participation of women vaidus in these programs has helped in their improved recognition. 'In the past, our expertise was perceived to midwifery skills. But now we also treat people as male vaidus do. Besides, our participation in programs like vaidu sammelan gives us a confidence and authority to take part in village conservation and development activities related to medicinal plans along with male vaidus' (JS, women vaidu, Amboli, March 2004). The women vaidus in particular and vaidus in general, are being regarded as equal partners, not only in generating a useful knowledge base about medicinal plants but also in developing an agenda for their conservation and sustainable use.

At the district level, the Forest Department publicized the contributions of the vaidus through a special publication or in their working plans. For example, the district Forest Department of Sindhudurg and RCMPCC published a Marathi language booklet with the list and uses of 100 local medicinal plants. The Latin, English and vernacular names of the plants are listed along with their family names. In addition, a list of 113 vaidus with their areas of specialization and addresses is provided in the book. The book has been widely circulated among state forest officials, other state government departments, universities and NGOs. 'We have publicly honoured vaidus from Amboli. Some vaidus that were listed in the booklet are now being invited by NGOs and Other government departments to participate in training and share their stories' (RN, Forester, Sidhudurg Division, December 2003). The Forest Department has also recognized vaidus as ecoguides in Koynanagar. RCMPCC complemented these efforts by involving vaidus in developing and maintaining demonstration gardens, home herbal gardens and interpretation centres and in documenting sacred groves (the local areas that were conserved by villagers for religious or spiritual purposes).

At the state level, the collective documentation and collaborative research with the vaidus, helped in creating a database of medicinal plants and herbal formulations.
These databases provided useful information about the Rare, Endangered and Threatened (RET) plant species that were prioritized for conservation and regeneration in the working plans of Forest Department. 'The research, documentation and database development efforts of RCMPCC with vaidus and communities, earned us an honour of 'Resource institution' in the State Medicinal plant board and Forest Department' (RCMPCC management board representative, Pune, March 2004).

At the national level, these approaches mobilized funding support for the two studies from the Department of Science and Technology and the Ministry of Tribal affairs on standardization of selected medicinal plants in six MPCAs and a biodiversity register in one MPCA, respectively. Vaidus from all thirteen MPCAs (three from each site) participated in the National Herbal Expo in 2000 and 2001 where they had shown their herbal products and had an opportunity to interact with government officials, NGO representatives and vaidus from other states.

The most visible national and global impacts of these approaches were the inclusion and recognition of vaidus as important project stakeholders in the new conservation and development funding plans that nine other states of India have submitted to the Global Environment Facility (GEF) for funding. The unique endemic plant species of Ceropegia spp. was discovered in Leghapani MPCA. [20]. 'Our vaidus have guided researchers form International Tropical Timber Organisation (ITTO) from Japan and helped them organize transects by identifying suitable pockets' (MA, Key leader, RCMPCC, December, 2003).

These impacts and outcomes constitute, what scholars of community-based conservation describe as 'benefits'equity and empowerment being the key considerations [21]. The vaidus and their medicinal plant knowledge, have been recognized, legitimized and in some cases built upon to meet the medicinal plant conservation and development goals at various levels.

It is evident from the material in Table 2, that the activities of the RCMPCC generated some useful outcomes at the village, regional, state and national levels, rather than the global level. The national level outcomes (largely driven by the RCMPCC) include: the mobilization of funding commitments through pilot research projects on RET species, a biodiversity register in one MPCA and the recognition of the contributions of the vaidus in country-wide publications and national exhibitions. These outcomes have yielded some legitimization to and official use of the local medicinal plant knowledge and its holders (vaidus). At the state level, the recognition and support to the vaidus reflected through examples of the documentation on botanical and local nomenclature for plants, validation of 
medicinal uses of plant (as reported by the (vaidus) by Ayurvedic practitioners and botanists and collaboration with formal scientists for collective identification of the priority areas/species for conservation, simple resource mapping and herbarium development. At the global level, there has been some acknowledgment of the contributions of the vaidus as evident from their involvement in scientific studies.

The availability and acceptability of vaidus at the village level and their legitimacy, recognition and partnerships at the state and national levels, created a sense of empowerment (that they can decide and implement local conservation and development agenda) and equity (that their knowledge can inform and interact with knowledge of formally trained botanists or foresters). While these most sought-after benefits of community-based conservation may be achieved at the village and district levels, their fullest potential is yet to be realized at the state, national and global level.

\section{Conclusion}

In India, although the majority of the population still relies on local knowledge systems to meet their health needs, the official policies and national support structures are inadequate for TSM and almost absent for folk medicine. NGOs like the RCMPCC have demonstrated that community-based approaches such as the vaidu sammelan and the village biologist programs can provide a platform on which holders of local medicinal plant knowledge systems (both folk and TSM) can interact with the holders of formal knowledge (e.g. botanists and other scientists). These approaches have also generated positive outcomes at different levels, such as the legitimization and recognition of the folk knowledge of the village vaidus in the district, state and (externally-aided) national plans of the Forest Department, the mobilization of collaborative research and funding commitments by the government departments, NGOs and research institutions at the state and the national levels and, most importantly, the pre-testing of community-based educational models for facilitating transmission of folk knowledge associated with uses of medicinal plants at the village or the sub-state levels. These outcomes show a way to achieve the larger goals of equity and empowerment as conceived in community-based conservation. In this case of communitybased medicinal plant conservation, however, the achievement of these important goals is limited to local, district and, to a certain extent, state level. In order to make these goals more durable and widespread, such community-based approaches that build on local medicinal plant knowledge systems need to be encouraged with supportive policy and legislative measures at the national and the global levels.

\section{Competing interests}

We do not have any monetary competing interest. This research was undertaken as a part of PhD thesis and therefore authors have academic interest.

\section{Authors' contributions}

SS designed, carried out and analyzed the field research. JG helped in conceptualization of the study, supervised the study and significantly contributed in the improvement of this manuscript. All authors read and approved the final manuscript.

\section{Acknowledgements}

Dr John Sinclair and Dr Fikret Berkes provided continuous guidance and friendly support throughout this research. Ms Kritin Kent provided very useful and constructive editorial comments. The funding support from Social Science and Humanities Research Council of Canada (SSHRC) and IDRC, Canada is gratefully acknowledged. Author wishes to acknowledge the generous support and cooperation of RCMPCC, Pune particularly $\mathrm{Mr}$ Muneer Alavi, Mr Brigadier Kaul, Dr Suresh Jagtap, Mr Vivek Gourbroome, Mr Satish Eklunchwar, Dr Vaishali Gawandi. Dr. Utkarsh Ghate and Dr. Darshan Shankar provided valuable insights about local knowledge systems and access to FRLHT, Bangalore. The officials and staff from the Maharashtra Forest department particularly, Mr. Bhangre, Mr. Majumdar, Mr Gogte, Mr.Khaire, Mr. Rajadne, Mr. Shivram, Mr Kashiram, have been helpful in providing useful data on the study. Finally, without the warm support and cooperation of the local management committee, healers and villagers of Amboli particularly Mr Dilip Sawant, Mr Arun Chawan Mr Anthony, Mr Anirudhha, Ms Merry D'souza, Ms Anita Sawant, Ms Dixita Guruv, Mr Shailesh Mehtar, Mr Prashant and Mr Suresh the local field work in Amboli would not have been possible. The review by two anonymous referees provided valuable direction in improving the draft. Usual disclaimers apply.

\section{References}

I. Berkes F: Sacred Ecology: Traditional Ecological Knowledge and Resources Management Philadelphia: Taylor and Francis; 1999.

2. Foundation for Revitalization of Local Health Traditions(FRLHT): [http://www.frlht.org.in/]. Bangalore: FRLHT (Accessed 22 June 2005)

3. Nelson JG: Research in human ecology and planning: an interactive, adaptive approach. The Canadian Geographer 1991, 35(2): I I4- I 27

4. Rural Commune's Medicinal Plant Conservation Center: Conservation of Medicinal Plants in Maharashtra State, Status and Progress Paper, Mimeo, Pune: RCMPCC 2003.

5. Silverman D: Doing qualitative research: A Practical handbook London; Thousand Oaks: SAGE; 2005.

6. World Health Organization: Traditional Medicines Strategy 2002-2005 Geneva: WHO; 2002.

7. Nickel W, Sennhauser E: Medicinal Plants: Local heritage with Global importance [http://lnwebl8.worldbank.org/sar/sa.nsf/0/ fae63d87e2bd I 4038525687f0057e0dl?OpenDocument]. World Bank Group, South Asia Accessed 2I August 2005

8. Schippmann $U$, Leaman DJ, Cunningham AB: Impact of cultivation and gathering of medicinal plants on biodiversity: global trends and issues InterDepartment Working Group on Biology Diversity for Food and Agriculture, Rome, Italy: Food and Agriculture Organizations (FAO); 2002.

9. Hamilton A: Medicinal plants and conservation: issues and approaches Surrey, U.K.: International plants Conservation Unit, WWF-UK; 2005.

10. Shankar DS: Revitalizing local health traditions. In Food for thought: ancient visions and new experiments of rural people Edited by: Haverkort B, Wim Hiemstra. London: Zed Books; 1999:43-5I.

11. Shankar DS: Agenda for Revitalization of Indian Medical Heritage New Delhi, India: Voluntary Health Association of India (VHAl); $200 \mathrm{I}$. 
12. Gupta AK: Conserving Biodiversity and Rewarding Associated Knowledge and Innovation system: Honey Bee Perspective 1999 [http:// www.sristi.org/pub.html]. Invited paper for the first Commonwealth Science Forum-Access, Bio prospecting, Intellectual Property Rights and Benefit Sharing and the Commonwealth, Ahmedabad: SRISTI

13. Kala CP: Revitalizing Traditional Herbal Therapy by Exploring Medicinal Plants: A Case Study of Uttaranchal State in India. Proceedings of the International Conference on Indigenous knowledge: Transforming the Academy: 27-28 May 2004 2004:15-22 [http:app.outreach.psu.edu/IndigenousKnowledges/ default.asp? Which Page=Proceedings]. Pennsylvania, Penn State University (Accessed 19 January 2005)

14. Balasubramaniam AV: People's Knowledge in Health care. In Reading Material in Local Health Traditions Edited by: TSM, Foundation for Revitalization of Local Health Traditions. Bangalore: FRLHT; 2000:17-26.

15. Shankar DS, Venkatasubramanian P: The evolution of global standards for traditional medicines. IK Dossier on Science Development Network 2004 [http://www.scidev.net/dossiers/index.cfm?fuseaction=policy brief\&dossier=7\&policy=58]. (Accessed 27 August 2005)

16. Bodeker G: Medicinal plants: towards sustainability and security Oxford, UK: Green College; 2002.

17. National Medicinal Plants Board's website 2004 [http:// www.nmpb.nic.in]. (Accessed 2 I October 2005)

18. Shukla SR, Gardner JS: Lessons from the Equator Initiative: Rural Commune's Medicinal Plant Conservation Centre, Pune, India: A Technical Report 2004 [http://www.umanitoba.ca/institutes/natural resources/ nri cbrm projects eiprojects.html]. Winnipeg: Centre for Community-Based Resource Management, Natural Resources Institute University of Manitoba (Accessed 24 June 2005)

19. Rural Commune's Medicinal Plant Conservation Center: Village Biologist Concept Note Mimeo Pune: RCMPCC; 1999.

20. Jagtap $S$, Deokule $S$, Watve $A$ : Occurrence of threatened fragrant Ceropegia in Toranmal Forest, Maharashtra. Current Science 2004, 27(5):553-554.

21. Berkes F: Re-thinking community-based conservation. Conservation Biology 2004, 18(3):62I-630.

\section{Publish with Bio Med Central and every scientist can read your work free of charge}

"BioMed Central will be the most significant development for disseminating the results of biomedical research in our lifetime. "

Sir Paul Nurse, Cancer Research UK

Your research papers will be:

- available free of charge to the entire biomedical community

- peer reviewed and published immediately upon acceptance

- cited in PubMed and archived on PubMed Central

- yours - you keep the copyright

Submit your manuscript here:

http://www.biomedcentral.com/info/publishing_adv.asp
Biomedcentral 